\title{
Wpływ kontekstowego bodźca dotykowego na percepcję smaku czekolady
}

\begin{abstract}
The present experimental study refers to the research into multisensory perception, in this case, the combination of tactile and taste senses. The investigation is focused on the relationship between the properties of the tactile stimulus accompanying yet unrelated to the process of eating and the taste perception of milk chocolate. The subjects, standing barefoot on either soft or hard surface, consumed a piece of chocolate and then evaluated if it was sweet (assessment of the principal taste dimension), whether they liked it and if it melted in their mouth (complex assessments). It was only in a situation of complex taste evaluation that chocolate was evaluated higher when it was consumed while participants were standing on a soft rather than a rough surface; on the other hand perception of the principal flavour dimension, i.e. sweetness, did not depend on the properties of the contextual tactile stimulus.
\end{abstract}

Keywords: taste perception, cross-modal tactile-taste interactions

\section{Wprowadzenie teoretyczne}

Zagadnienie oddziaływania na siebie różnych modalności zmysłowych interesuje badaczy od dawna, a obecnie poznanie wielozmysłowe stanowi jeden $\mathrm{z}$ ważniejszych obszarów zainteresowań psychologii poznawczej ${ }^{1}$. Początkowo badania dotyczące wzajemnego oddziaływania na siebie modalności koncentrowały się na zjawisku synestezji, którą można rozumieć jako zdolność do „(...) surrealistycznego łączenia wrażeń, postrzeżeń i emocji” [Ramachandran, 2012, s. 97]. Już na początku XX wieku analizowano fenomeny synestetów [zob. Galeyev i Vanechkina, 2001], a obecnie wiadomo, że wśród wielu form synestezji występuje między innymi synestezja dotyk-smak (najbardziej powszechną formą jest synestezja liczba-kolor). Ramachandran [2012] podaje przypadek pacjentki o imieniu Francesca, u której dotyk wywoływał wrażenia smakowe, na przykład głaszcząc kute żelazo, czuła ona w ustach intensywny, słony smak. Choć synestezja jest zjawiskiem relatywnie rzadkim, z badań nad percepcją smaku wynika, że poszczególne smaki powszechnie kojarzą się z określonymi kształtami, słowami i dźwiękami, a także że ludzie powszechnie stosują metaforycz-

${ }^{1}$ Niemniej jednak większość prowadzonych na tym gruncie analiz dotyczy wzajemnych związków percepcji wzrokowej, dotykowej i słuchowej [zob. Stein, 2012], natomiast przedmiotem relatywnie niewielu eksperymentów jest percepcja smaku. 
ne nazwy na określenie pewnych doznań smakowych (np. smak głęboki, ciemny) [Crisinel i Spence, 2010; Ngo, Misra i Spence, 2011; Ngo i Spence, 2011; Spence i Deroy, 2013]. Czekolada wywołuje różne skojarzenia w zależności od zawartości w niej kakao oraz tego, czy jest nadziewana [Ngo, Misra i Spence, 2011; Ngo i Spence, 2011]. Czekolada mleczna przez większość osób kojarzona jest z czymś przyjemnym, a także z organicznymi, zaokrąglonymi kształtami oraz miękko brzmiącymi słowami (jak „maluma” - które kojarzą się też z miękkimi, gładkimi obiektami), zaś gorzka - z kanciastymi kształtami i ostro (szorstko, twardo) brzmiącymi słowami (jak „takete” - które kojarzą się też z twardymi, szorstkimi obiektami). Z kolei czekolada miętowa $\mathrm{w}$ mniejszym stopniu kojarzona jest $\mathrm{z}$ zaostrzonymi kształtami, gdy jest ona nadziewana.

Odczuwany przez człowieka smak (flavour) zależy nie tylko od informacji odbieranej przez rozmieszczone na języku receptory [Spence, 2010]. Na doznania smakowe ma wpływ wiele czynników, poczynając od wrażeń płynących z innych modalności związanych z samym pokarmem (m.in. jego zapach, wygląd, temperatura, konsystencja), poprzez zmienne, które towarzyszą procesowi jedzenia czy picia (np. wystrój otoczenia, tzw. krajobraz dźwiękowy), kończąc na czynnikach poznawczych i emocjonalnych (np. czy podczas jedzenia równocześnie myślimy o czymś przyjemnym, czy nieprzyjemnym; czy posiadamy wiedzę dotyczącą ceny konsumowanego produktu) [por. Auvray i Spence, 2008; Delwiche, 2004; Plassmann i in., 2008]. Wpływ zmiennych kontekstowych towarzyszących sytuacji jedzenia na odczuwany smak można opisać na co najmniej trzech poziomach, które dotyczą manipulacji: (1) kluczowymi aspektami samego ocenianego jedzenia (np. kolor, zapach, tekstura); (2) zewnętrznym kontekstem, w jakim pojawia się posiłek (np. elegancko bądź nieelegancko podany); (3) kontekst zupełnie niezwiązany z samym posiłkiem czy formą jego podania - co stanowi przedmiot eksperymentu opisanego w niniejszym artykule.

Wpływ zmiennych kontekstowych, jakimi są kluczowe aspekty samego ocenianego jedzenia, na percepcję smaku może dotyczyć wpływu informacji węchowych, wzrokowych, słuchowych i dotykowych. Prawdopodobnie każdy podczas przebytej choroby doświadczył tego, że percepcja smaku pokarmów jest stłumiona, gdy nie doświadczamy ich zapachu. Mówimy wówczas, że nie czujemy smaku, co w istocie oznacza, że trudno jest nam różne smaki identyfikować. Hyman, Mentzer i Calderone [1979] przeprowadzili eksperyment, w którym zadaniem badanych było określanie smaku napojów (do degustacji podawano napoje smakowe oraz wodę) w trzech różnych warunkach: smakowanie i wąchanie, tylko smakowanie i tylko wąchanie. Aby uniknąć możliwych zniekształceń w ocenie, spowodowanych przez wskazówki wzrokowe, badani dokonywali oceny z zasłoniętymi oczami. Badacze stwierdzili, że detekcja syropu czekoladowego w napoju była trafniejsza w sytuacji, gdy badani mieli możliwość smakowania i wąchania, niż w sytuacji, gdy smak oceniano, korzystając jedynie z jednego ze zmysłów - smaku bądź węchu. Ponadto informacja węchowa może zmieniać percepcję smaku. Wąchanie różnych aromatów sprawia, że mamy określone oczekiwania odnośnie do smaku pokarmów, a także inaczej odczuwamy ich smak [Djordjevic, Zatorre i Jones-Gotman, 2004; Lawrence i in., 2009]. Renomowani restauratorzy dbają o to, by podawane przez nich dania pięknie wyglądały, intuicyjnie kierując się zasadą, zgodnie z którą atrakcyjniejszy wizualnie posiłek bardziej 
smakuje. Zjawisko „jedzenia oczami” [por. Delwiche, 2012] analizowano empirycznie, badając percepcję smaku w zależności od różnych związanych z posiłkiem wskazówek wzrokowych, w tym koloru. Zampini i współpracownicy [2007] stwierdzili, że percepcja smaku zależy od koloru pokarmu, nawet w sytuacji, gdy badani byli wprost informowani o tym, że kolor może być mylący (np. gdy oceniali smak napoju o smaku pomarańczowym, który miał zielony kolor). Wpływ informacji słuchowej na ocenę smaku badano, między innymi sprawdzając, w jaki sposób charakterystyki dźwięku wywołanego gryzieniem chipsów zmieniają ocenę chrupkości tej przekąski [Zampini i Spence, 2004]. Ocena smaku może również zależeć od dotykowych walorów zjadanych pokarmów. Odczuwana słodkość zależy od gęstości pokarmu - gęstsze pokarmy wydają nam się mniej słodkie niż te o luźniejszej konsystencji [Cook i in., 2002; Knoop i in., 2013). Artykuły żywnościowe oceniane są jako bardziej kwaśne, gdy ich powierzchnia jest chropowata, niż gdy jest gładka [Slocombe, Carmichael i Simner, 2015], zaś ocena świeżości jedzonych precli (paluszków) zależy od wskazówek dotykowych [Barnett-Cowan, 2010].

Zewnętrzny kontekst, w jakim pojawia się posiłek, może dotyczyć cech zastawy, na której się go serwuje. Stewart i Goss [2013] stwierdzili interakcyjny wpływ kształtu i koloru talerza, na którym podano sernik, na ocenę smaku ciasta. Z kolei Piqueras-Fiszman i Spence [2012a] empirycznie wykazali, że kolor kubka, z którego pijemy gorącą czekoladę, zmienia percepcję smaku i lubienie tego napoju. Waga sztućców, których używamy do jedzenia, a także miseczek, w których znajduje się posiłek, ma zaś wpływ na ocenę smaku i sytości pokarmów [Piqueras-Fiszman i Spence, 2012b; Spence i Piqueras-Fiszman, 2014].

Celem badania własnego było sprawdzenie, czy kontekstowe czynniki dotykowe niezwiązane ze zjadanym produktem, ale towarzyszące sytuacji konsumowania, zmieniają ocenę smaku. Jak dotąd empirycznie stwierdzono, że na percepcję smaku wpływa niezwiązany z jedzeniem kontekst wzrokowy (oświetlenie otoczenia) [np. Oberfeld i in., 2009] i słuchowy (charakterystyki dźwięków docierających do jedzącej osoby) [np. Spence, 2014; 2015].

W badaniu własnym wpływ informacji dotykowej na ocenę smaku analizowano na przykładzie czekolady - produktu, który jest chętnie degustowany przez większość konsumentów, a ponadto doczekał się już wielu analiz na gruncie psychologii percepcji. Ponieważ wskazówki wzrokowe i zapachowe mogą zmieniać percepcję smaku dań, zdecydowano się, że podczas badania jego uczestnicy - osoby, które nie cierpią aktualnie z powodu kataru, będą miały zasłonięte oczy. Analizowaną wskazówką kontekstową były dotykowe własności powierzchni, na której stano, jedząc czekoladę. Postawiono hipotezę, zgodnie z którą smak czekolady jest oceniany inaczej w sytuacji, gdy konsument znajduje się na miękkiej i gładkiej powierzchni niż na szorstkiej i twardej. Może to wynikać między innymi z tego, że gładkie, miękkie powierzchnie kojarzą się z czymś przyjemnym. Percepcję smaku oceniano na trzech wymiarach, pytając badanych o wartościowanie słodkości czekolady, tego, czy im smakuje oraz czy rozpływa się w ustach. Odczuwaną słodkość uznaje się za prosty element oceny smaku, zaś ewaluację tego, w jakim stopniu czekolada rozpływa się w ustach i czy smakuje konsumującym ją osobom, należałoby traktować jako złożoną ocenę smaku czy też ocenę wyższego stopnia [por. Stewart i Goss, 2013; Delwiche, 2012]. Dodatko- 
wym celem badania było sprawdzenie, czy oceniane wymiary percepcji smaku czekolady są ze sobą skorelowane: czy czekolada smakuje konsumentom bardziej, gdy jest oceniana jako słodsza i bardziej rozpływająca się w ustach?

\section{Metoda}

\section{Osoby badane}

Badana próba składała się z 32 studentów (16 kobiet i 16 mężczyzn) w wieku 18-25 lat $(\mathrm{M}=21,06$ lat, $\mathrm{SD}=1,93)$. Osoby te nie cierpiały na żadne choroby związane ze zmysłem smaku ani powonienia i w momencie badania nie miały kataru.

\section{Materiały i aparatura badawcza}

W badaniu użyto kostki mlecznej czekolady marki Wedel, kubeczka z wodą, a także wycieraczki (tj. powierzchni, która jest twarda i szorstka) i puchowej poduszki (tj. powierzchni, która jest miękka i gładka) o zbliżonych wymiarach. Do pomiaru czasu wykorzystano stoper.

\section{Procedura}

Badanie prowadzono indywidualnie, $\mathrm{w}$ planie $\mathrm{z}$ powtarzanym pomiarem. Wszyscy badani jedli czekoladę w dwóch warunkach: stojąc na wycieraczce oraz ułożonej na podłodze poduszce. Podczas jedzenia czekolady badani mieli zasłonięte oczy i bose stopy. Wybór lokalizacji wrażeń dotykowych miał zapewnić ich wyrazistość (której prawdopodobnie nie osiągniętoby, gdyby np. proszono osoby badane o siadanie na miękkich lub twardych siedziskach - ze względu na różny stopień miękkości ubrań). Kontrolowano też kolejność jedzenia czekolady - połowa badanych najpierw jadła czekoladę, stojąc na wycieraczce, a potem na poduszce, a połowa badanych czyniła to w odwrotnej kolejności. Mierzono czas jedzenia kostki mlecznej czekolady - od momentu włożenia jej do ust do momentu zasygnalizowania przez badanego, że została ona zjedzona. Po skonsumowaniu pierwszej kostki czekolady badani ustosunkowywali się do trzech twierdzeń dotyczących percepcji smaku. Następnie przepłukiwali usta wodą i stawali na innej powierzchni, po czym zjadali drugą kostkę i ponownie dokonywali oceny. Ocen dokonywano w siedmiostopniowej skali. Badani oceniali, w jakim stopniu zgadzają się z następującymi twierdzeniami: „Czekolada była słodka”; "Czekolada smakowała mi”; „Czekolada rozpływała mi się w ustach”. Wartości skrajne skali opisano następująco: „zdecydowanie nie” (1); „zdecydowanie tak” (7). 
Wyniki $^{2}$

Dla wszystkich ocenianych w badaniu wskaźników percepcji smaku przeprowadzono odrębną analizę wariancji z powtarzanym pomiarem dla czynnika wewnątrzobiektowego podłoże (wycieraczka; poduszka) i zmiennej międzyobiektowej kolejność warunków jedzenia (wycieraczka-poduszka; poduszka-wycieraczka). Dodatkowo wykonano analogiczną analizę, żeby sprawdzić, czy czas jedzenia czekolady w poszczególnych warunkach eksperymentalnych jest różny, nie stwierdzając istotnie statystycznych różnic ani ze względu na zmienną podłoże, $\mathrm{F}(1,30)=0,67, \mathrm{p}=$ 0,419, ani zmienną kolejność warunków jedzenia, $\mathrm{F}(1,30)=3,76, \mathrm{p}=0,062$, ani interakcji analizowanych czynników, $\mathrm{F}(1,30)=0,1, \mathrm{p}=0,757$. Statystyki opisowe wszystkich analizowanych zmiennych zamieszczono w tabeli 1 .

Tabela 1. Statystyki opisowe (średnie i odchylenia standardowe) dla oceny: percepcji słodyczy czekolady; tego, czy rozpływa się ona w ustach, i tego, czy smakowała konsumentom (skala 7-stopniowa, wyższy wynik oznacza większy stopień zgadzania się z poszczególnymi twierdzeniami), oraz czasu jedzenia pojedynczej kostki czekolady (mierzony w sekundach)

\begin{tabular}{|l|c|c|c|c|c|c|c|c|}
\hline & \multicolumn{4}{|c|}{ Jedzenie na wycieraczce } & \multicolumn{5}{c|}{ Jedzenie na poduszce } \\
\cline { 2 - 9 } & $\begin{array}{c}\text { Kolejność jedzenia: } \\
\text { wycieraczka- } \\
\text { poduszka }\end{array}$ & $\begin{array}{c}\text { Kolejność jedzenia: } \\
\text { poduszka- } \\
\text { wycieraczk }\end{array}$ & $\begin{array}{c}\text { Kolejność jedzenia: } \\
\text { wycieraczka- } \\
\text { poduszka }\end{array}$ & $\begin{array}{c}\text { Kolejność jedzenia: } \\
\text { poduszka- } \\
\text { wycieraczka }\end{array}$ \\
\cline { 2 - 10 } & $M$ & $S D$ & $M$ & $S D$ & $M$ & $S D$ & $M$ & $S D$ \\
\hline $\begin{array}{l}\text { Czekolada } \\
\text { była słodka }\end{array}$ & 5,13 & 1,59 & 5,63 & 1,36 & 5,50 & 1,21 & 6,19 & 1,28 \\
\hline $\begin{array}{l}\text { Czekolada } \\
\text { smakowała mi }\end{array}$ & 4,88 & 2,16 & 5,75 & 1,06 & 5,69 & 1,08 & 6,44 & 0,73 \\
\hline $\begin{array}{l}\text { Czekolada } \\
\text { rozpływała mi } \\
\text { się w ustach }\end{array}$ & 4,25 & 1,84 & 4,81 & 1,42 & 5,31 & 1,45 & 5,63 & 1,41 \\
\hline Czas & 44,31 & 22,07 & 63,25 & 33,97 & 45,69 & 23,94 & 66,31 & 36,80 \\
\hline
\end{tabular}

\section{Ocena czekolady}

Nie stwierdzono istotnych statystycznie różnic w ocenie słodkości ze względu na podłoże $\mathrm{F}(1,30)=3,53, \mathrm{p}=0,070$, kolejność warunków jedzenia, $\mathrm{F}(1,30)=2,06, \mathrm{p}=$ 0,161 , ani interakcji analizowanych czynników, $\mathrm{F}(1,30)=0,14, \mathrm{p}=0,71$.

Oceny tego, w jakim stopniu czekolada smakuje konsumentom, zależały od rodzaju podłoża, na którym stali, $\mathrm{F}(1,30)=5,41, \mathrm{p}=0,027, \eta^{2}=0,15$ oraz od kolejności warunków, w jakiej jedli każdą z kostek czekolady, $\mathrm{F}(1,30)=5,10, \mathrm{p}=0,031, \eta^{2}=$ 0,15 . Czekolada bardziej smakowała osobom, które jadły ją, stojąc na poduszce $(\mathrm{M}=$

2 Dane do analiz przeprowadzonych w niniejszym raporcie zebrały: Aneta Gołyska, Karolina Miś, Katarzyna Oborska i Magdalena Pietnoczko. Wszystkim Paniom serdecznie dziękuję za wykonaną pracę. 
$6,06 ; \mathrm{SD}=0,98)$ niż na wycieraczce $(\mathrm{M}=5,31 ; \mathrm{SD}=1,73)$. Ponadto czekolada była oceniana łącznie (ocena z obydwu pomiarów) jako smaczniejsza w grupie, która jadła ją w kolejności: poduszka $\rightarrow$ wycieraczka $(M=6,09 ; \mathrm{SD}=0,96)$, niż w grupie, która jadła ją w kolejności wycieraczka $\rightarrow$ poduszka $(M=5,28 ; S D=1,72)$. Interakcja analizowanych czynników nie była istotna statystycznie, $\mathrm{F}(1,30)=0,04, \mathrm{p}=0,848$.

W sytuacji ocena tego, czy czekolada rozpływa się w ustach, otrzymano efekt główny czynnika podłoże, $\mathrm{F}(1,30)=4,98, \mathrm{p}=0,033, \eta^{2}=0,14$. Uznawano, że czekolada bardziej rozpływa się w ustach, gdy jedzono ją, stojąc na poduszce $(M=5,47$; $S D$ $=1,41)$ niż stojąc na wycieraczce $(\mathrm{M}=4,53 ; \mathrm{SD}=1,65)$. Nie stwierdzono istotnych statystycznie różnic ze względu na kolejność warunków jedzenia, $\mathrm{F}(1,30)=1,59, \mathrm{p}=$ 0,218 , ani interakcji analizowanych czynników, $\mathrm{F}(1,30)=0,09, \mathrm{p}=0,768$.

Po obliczeniu współczynniki korelacji $r$ Pearsona dla ocen dokonanych na poszczególnych wymiarach percepcji smaku, osobno dla warunków stania na wycieraczce i poduszce, okazało się, że wszystkie analizowane wymiary oceny korelowały ze sobą istotnie. Wszystkie otrzymane korelacje były dodatnie (zob. tabela 2).

Tabela 2. Wartość i istotność współczynników korelacji $r$ Pearsona dla poszczególnych aspektów oceny smaku

\begin{tabular}{|l|c|c|}
\hline & $\begin{array}{c}\text { Kontekst dotykowy: } \\
\text { wycieraczka }\end{array}$ & $\begin{array}{c}\text { Kontekst dotykowy: } \\
\text { poduszka }\end{array}$ \\
\hline $\begin{array}{l}\text { Czekolada była słodka - } \\
\text { Czekolada smakowała mi }\end{array}$ & $r=0,69 ; \mathrm{p}<0,001$ & $r=0,47 ; \mathrm{p}=0,006$ \\
\hline $\begin{array}{l}\text { Czekolada była słodka - } \\
\text { Czekolada rozpływała mi się } \\
\text { w ustach }\end{array}$ & $r=0,62 ; \mathrm{p}<0,001$ & $r=0,56 ; \mathrm{p}=0,001$ \\
\hline $\begin{array}{l}\text { Czekolada smakowała mi - } \\
\text { Czekolada rozpływała mi się } \\
\text { w ustach }\end{array}$ & $r=0,65 ; \mathrm{p}<0,001$ & $r=0,44 ; \mathrm{p}=0,011$ \\
\hline
\end{tabular}

\section{Dyskusja wyników}

Celem badania była analiza dotykowych wskaźników kontekstowych niezwiązanych ze spożywanym pokarmem na percepcję smaku. Postawiona hipoteza, zgodnie z którą smak czekolady jest oceniany inaczej w sytuacji, gdy konsument stoi boso na miękkiej i gładkiej powierzchni niż na powierzchni szorstkiej i twardej, została częściowo potwierdzona. Czekolada była oceniana jako smaczniejsza i bardziej rozpływająca się w ustach, gdy jedzono ją, stojąc na poduszce, w porównaniu z sytuacją, gdy jedzono ją, stojąc na wycieraczce. Czas jedzenia czekolady nie różnił się ze względu na cechy podłoża, na którym stano podczas konsumpcji - a zatem otrzymane różnice $\mathrm{w}$ ocenie tego, czy czekolada rozpływa się w ustach, możemy przypisać temu, że badani do określenia "rozpływa się w ustach" odnosili się nie w sposób dosłowny. Innymi słowy, wyższy wynik na skali rozpływania się w ustach można tu trakto- 
wać jako wskaźnik wykwintności czy delikatności smaku czekolady - interpretację tę potwierdza otrzymana dodatnia korelacja ocen tego, czy czekolada rozpływała się w ustach i czy smakowała osobie, która ją zjadła. Otrzymane wyniki potwierdzają znany już efekt wpływu informacji dotykowej na percepcję smaku [Barnett-Cowan, 2010; Cook i in., 2002; Knoop i in., 2013; Slocombe, Carmichael i Simner, 2015), a jednocześnie poszerzają dotychczasową wiedzę na temat modyfikacji odczuwanego smaku przez dotykowe własności bodźców. $\mathrm{Z}$ wcześniejszych badań wynika, iż percepcja smaku zmienia się pod wpływem dotykowych cech samego pożywienia, jak jego konsystencja [Cook i in., 2002; Knoop i in., 2013], miękkość [Barnett-Cowan, 2010] czy struktura powierzchni [Slocombe, Carmichael i Simner, 2015]. W badaniu własnym pokazano natomiast, że percepcja smaku zależy także od dotykowych własności bodźca kontekstowego, który występuje w sytuacji jedzenia, ale nie jest związany z samym pokarmem.

Nie stwierdzono zakładanego $\mathrm{w}$ hipotezie wpływu dotykowych własności powierzchni, na której stano podczas jedzenia, na ocenę słodkości czekolady. Ocenę słodkości uznaje się za prosty element oceny smaku - w przeciwieństwie do złożonej oceny wyższego stopnia, która może dotyczyć między innymi tego, czy jedzenie nam smakuje lub czy rozpływa się ono w ustach [por. Stewart i Goss, 2013; Delwiche, 2012]. Stewart i Goss [2013] zauważyli, że kontekstowa informacja wzrokowa w inny sposób wpływa na ocenę smaku na wymiarze prostym i złożonym. W badaniach własnych analogiczny rezultat odnotowano, badając wpływ dotykowej informacji kontekstowej na ocenę smaku. Wpływ dotykowej informacji kontekstowej uwidocznił się w sytuacji oceny złożonej, zaś ocena prostych cech smaku (jak słodkość) okazała się niezależna od własności dotykowych bodźca kontekstowego. Co ciekawe, stwierdzono, że ocena prostych i złożonych cech smaku czekolady jest ze sobą dodatnio skorelowana - a więc mleczna czekolada jest bardziej preferowana (oceniana jako smaczniejsza), jeśli jest słodsza i jeśli sprawia wrażenie bardziej rozpływającej się w ustach.

Ponadto okazało się, że dla oceny tego, czy czekolada jest smaczna, znaczenie ma kolejność warunków kontekstu dotykowego, w którym jest jedzona. Czekolada była oceniana jako smaczniejsza, gdy najpierw jedzono ją, stojąc na poduszce, a następnie na wycieraczce, niż gdy czyniono to w odwrotnej kolejności. Otrzymany rezultat może mieć związek z efektem torowania - doświadczany smak pierwszej zjedzonej kostki czekolady mógł wpłynąć na doświadczany smak drugiej kostki. Ponieważ czekolada jedzona podczas stania na poduszce oceniana była jako smaczniejsza, następnie jedzona kostka, już w warunkach stania na wycieraczce, także wydała się bardziej smaczna. Odwrotnie było, gdy jedzenie czekolady rozpoczynano w kontekście dotykania stopami wycieraczki - czekolada smakowała wówczas badanym w mniejszym stopniu, co rzutowało na ocenę smaku kostki jedzonej następnie w kontekście stania na poduszce. Interpretację tę należy jednak traktować ostrożnie (w kategoriach hipotezy wymagającej rozstrzygnięcia empirycznego w kolejnych eksperymentach), otrzymany rezultat mógł bowiem wynikać także z tego, że w pierwszej grupie eksperymentalnej - osób, które jadły czekoladę, stojąc najpierw na poduszce, a następnie na wycieraczce - znalazło się więcej wielbicieli mlecznej czekolady niż w drugiej grupie eksperymentalnej (gdzie czekoladę jedzono, najpierw stojąc na wycieraczce, a następnie na poduszce). 
Prezentowane badanie ma pewne ograniczenia. Po pierwsze, dotyczyło ono jednego produktu spożywczego, tj. mlecznej czekolady. W przyszłości warto poszerzyć je o percepcję smaku innych produktów spożywczych, dodatkowo kontrolując to, $\mathrm{w}$ jakim stopniu produkty te są przez osoby badane preferowane (czy często je jedzą? czy im smakują?). Mleczna czekolada większości osób kojarzy się z miękko brzmiącymi bezsensownymi słowami („maluma” - te zaś kojarzą się z czymś przyjemnym), zaś inne rodzaje budzą inne skojarzenia [por. Ngo, Misra i Spence, 2011; Ngo i Spence, 2011]. Warto byłoby na przykład sprawdzić, czy czekolada gorzka nie sprawia wrażenia bardziej wyrazistej w smaku i lepszej w smaku, gdy jemy ją, doświadczając jednocześnie dotykowo bodźców szorstkich, twardych niż miękkich, gładkich (te bowiem zdają się bardziej „pasować” do czekolady mlecznej). Po drugie, badanie dotyczyło dotykania bosymi stopami wycieraczki bądź poduszki, a zatem analizowano wpływ wrażeń płynących z receptorów skórnych znajdujących się na wybranej, ograniczonej powierzchni ciała na ocenę smaku. W kolejnych badaniach warto byłoby przyjrzeć się temu, czy wpływ dotykowych cech bodźca kontekstowego niezwiązanego z jedzonym pokarmem wystąpi także podczas spożywania pokarmów w innych warunkach, na przykład siedzenia w miękkim fotelu lub na twardym krześle, czy dotykania gładkiej bądź szorstkiej powierzchni dłonią. Po trzecie, badano małe grupy osób. W związku z tym brak istotnego efektu głównego dla oceny tego, jak słodka jest czekolada, może wynikać zarówno z tego, że czynniki kontekstowe nie wpływają na ocenę elementarnych właściwości smakowych ${ }^{3}$, jak i być efektem niewystarczającej mocy testu (uzyskana wartość jest bliska wartości alfa 0,05, można ją więc traktować jako tendencję statystyczną, a kierunek zależności jest taki sam jak w przypadku pozostałych wymiarów oceny percepcji smaku).

Podsumowując, w czasach, gdy jedzenie stało się dla ludzi jedną z ważniejszych przyjemności, w których popularność zyskują liczne programy kulinarne, a coraz więcej osób interesuje się różnymi dietami, kontynuacja studiów nad percepcją smaku wydaje się z wielu powodów istotna. Poszerzenie wiedzy na temat wpływu dotykowych bodźców kontekstowych na percepcję różnych pokarmów (słodkich, słonych, kwaśnych, gorzkich, o smaku umami) jest ważne zarówno w kontekście rozwoju badań podstawowych nad poznaniem wielozmysłowym, jak i z punktu widzenia aplikacji. Z ich rezultatów z pewnością chętnie skorzystaliby renomowani restauratorzy czy producenci żywności.

\section{BIBLIOGRAFIA}

Auvray, M. i Spence, C. (2008). The multisensory perception of flavor. Consciousness and Cognition, 17: 1016-1031.

Barnett-Cowan, M. (2010). An illusion you can sink your teeth into: haptic cues modulate the perceived freshness and crispness of pretzels. Perception, 39: 1684-1686.

3 Stwierdzenie, że efekt rzeczywiście nie występuje, wymagałoby zastosowania metod Bayesowskich [por. Domurat i Białek, 2016]. 
Cook, D.J., Hollowood, T.A., Linforth, R.S.T. i Taylor, A.J. (2002). Perception of taste intensity in solutions of random-coil polysaccharides above and below. Food Quality and Preference, 13: 473-480.

Crisinel, A.-S. i Spence, C. (2010). As bitter as a trombone: Synesthetic correspondences in nonsynesthetes between tastes/flavors and musical notes. Attention, Perception, \& Psychophysics, 72: 1994-2002.

Delwiche, J.F. (2004). The impact of perceptual interactions on perceived flavor. Food Quality and Preference, 15: 137-146.

Delwiche, J.F. (2012). You eat with your eyes first. Physiology \& Behavior, 107: 502-504.

Djordjevic, J., Zatorre, R.J. i Jones-Gotman, M. (2004). Odor-induced changes in taste perception. Experimental Brain Research, 159: 405-408.

Domurat, A. i Białek, M. (2016). Dowodzenie hipotez za pomocą czynnika bayesowskiego (bayes factor): Przykłady użycia w badaniach empirycznych. Decyzje, 26: 109-141.

Galeyev, B.M. i Vanechkina, I.L. (2001). Was Scriabin a Synesthete? Leonardo, 34: 357-361.

Hyman, A., Mentzer, T. i Calderone, L. (1979). The contribution of olfaction to taste discrimination. Bulletin of the Psychanamic Society, 13: 359-362.

Knoop, J.E., Sala, G., Smit, G. i Stieger, M. (2013). Combinatory effects of texture and aroma modification on taste perception of model gels. Chemosensory Perception, 6: 60-69.

Lawrence, G., Salles, C., Septier, C., Busch, J. i Thomas-Danguin, T. (2009). Odour-taste interactions: A way to enhance saltiness in low-salt content solutions. Food Quality and Preference, 20: 241-248.

Ngo, M.K., Misra, R. i Spence, C. (2011). Assessing the shapes and speech sounds that people associate with chocolate samples varying in cocoa content. Food Quality and Preference, 22: $567-572$.

Ngo, M.K. i Spence, C. (2011). Assessing the shapes and speech sounds that consumers associate with different kinds of chocolate. Journal of Sensory Studies, 26: 421-428.

Oberfeld, D., Hecht, H., Allendorf, U. i Wickelmaier, F. (2009). Ambient lighting modifies the flavor of wine. Journal of Sensory Studies, 24: 797-832.

Piqueras-Fiszman, B. i Spence, C. (2012a). The influence of the color of the cup on consumers' perception of a hot beverage. Journal of Sensory Studies, 27: 324-331.

Piqueras-Fiszman, B. i Spence, C. (2012b). The weight of the container influences expected satiety, perceived density, and subsequent expected fullness. Appetite, 58: 559-562.

Plassmann, H., O’Doherty, J., Shiv, B. i Rangel, A. (2008). Marketing actions can modulate neural representations of experienced pleasantness. PNAS, 105: 1050-1054.

Ramachandran, V.S. (2012). Neuronauka o podstawach społeczeństwa. O czym mówi mózg? Warszawa: Wydawnictwo Uniwersytetu Warszawskiego.

Slocombe, B.G, Carmichael, D.A. i Simner, J. (2015). Cross-modal tactile-taste interactions in food evaluations. Neuropsychologia. DOI: 10.1016/j.neuropsychologia.2015.07.011.

Spence, C. (2010). The multisensory perception of flavour. The Psychologist, 23: 720-723.

Spence, C. (2014). Noise and its impact on the perception of food and drink. Flavour, 3: 9.

Spence, C. (2015). Eating with our ears: Assessing the importance of the sounds of consumption to our perception and enjoyment of multisensory flavour experiences. Flavour, 4: 3.

Spence, C. i Deroy, O. (2013). On the shapes of flavours: A review of four hypotheses. Theoria et Historia Scientiarum, 10: 207-238.

Spence, C. i Piqueras-Fiszman, B. (2014). The Perfect Meal: The Multisensory Science of Food and Dining. Oxford: Wiley-Blackwell.

Stein, B.E. (red.) (2012). The New Handbook of Multisensory Processing. Cambridge: The MIT Press.

Stewart, P.C. i Goss, E. (2013). Plate shape and colour interact to influence taste and quality judgments. Flavour, 2(27). DOI: 10.1186/2044-7248-2-27. 
Zampini, M., Sanabria, D., Phillips, N. i Spence, C. (2007). The multisensory perception of flavor: Assessing the influence of color cues on flavor discrimination responses. Food Quality and Preference, 18: 975-984.

Zampini, M. i Spence, C. (2004). The role of auditory cues in modulating the perceived crispness and staleness of potato chips. Journal of Sensory Studies, 19: 347-363. 